\title{
POPULATION ECOLOGY OF THE PLANKTONIC SHRIMP Lucifer faxoni BORRADAILE, 1915 (CRUSTACEA, SERGESTOIDEA, LUCIFERIDAE) OF THE SOUTHEASTERN COAST OF BRAZIL
}

\author{
Sarah de Souza Alves Teodoro ${ }^{1}$, Maria Lúcia Negreiros-Fransozo ${ }^{2}$, Sabrina Morilhas Simões ${ }^{1}$, \\ Mateus Lopes ${ }^{l}$ and Rogerio Caetano da Costa ${ }^{1 *}$ \\ ${ }^{1}$ Universidade Estadual Paulista "Julio de Mesquita Filho" - UNESP \\ Faculdade de Ciências, Departamento de Ciências Biológicas, Bauru \\ (Av. Eng. Luiz Edmundo Carrijo Coube, 14-01, 17033-360 Bauru, SP, Brasil) \\ ${ }^{2}$ Universidade Estadual Paulista "Julio de Mesquita Filho" - UNESP \\ Instituto de Biociências, Departamento de Zoologia - UNESP, Botucatu \\ (Distrito de Rubião Júnior, S/N, 18618-970 Botucatu, SP, Brasil) \\ *Corresponding author: rccosta@fc.unesp.br
}

\begin{abstract}
A B S T R A C T
Luciferid shrimps have short life spans and a rapid turnover of generations, engage in sequential spawning, and protect their eggs during incubation. This study investigates the ecology of Lucifer faxoni Borradaile, 1915 in the littoral zone, Ubatuba region, São Paulo. Sampling was conducted monthly from July 2005 to December 2006 using a Renfro net trawled over a distance of $50 \mathrm{~m}$ for a total sampling effort of $50 \mathrm{~m}^{2}$ at each station. Nine stations were sampled, ranging from 1 to $15 \mathrm{~m}$ deep. Three stations each were grouped into zones 1,2 and 3 (Z1, Z2 and Z3). Monthly values of salinity, temperature and rainfall were recorded at each station. The pre-buccal somite length (SL) of each specimen was measured. The results showed that in shallower zones (Z1 and Z2), 6306 individuals were captured, whereas in the deeper zone (Z3), 3808 specimens were captured, but no significant differences in SL was detected between the specimens from Z1 and Z2 and those from Z3 (ANOVA, $\mathrm{p}=0.25$ ). The abundance of shrimps did not differ significantly between seasons (Tukey's test, $\mathrm{p}=0.02)$ except in the spring. The sex ratio differed significantly over the seasons $\left(\chi^{2}, \mathrm{p}<0.05\right)$. The results were closely associated with environmental factors with respect to the spatial and seasonal distribution of L. faxoni. Rainfall affected salinity directly, and contributed to the displacement of these shrimps to deeper areas.
\end{abstract}

\section{RESUMO}

Este estudo analisa a ecologia de Lucifer faxoni Borradaile, 1915 em Ubatuba, São Paulo. Os indivíduos foram coletados mensalmente de julho de 2005 a dezembro de 2006, com uma rede de Renfro, arrastada por uma distância de $50 \mathrm{~m}$, totalizando um esforço amostral de $50 \mathrm{~m}^{2}$ em cada ponto de coleta. Nove pontos foram amostrados, variando de 1 a $15 \mathrm{~m}$ de profundidade. Cada 3 pontos foram agrupados em 3 zonas $(\mathrm{Z1}, \mathrm{Z} 2$ e Z3). Os valores de salinidade, temperatura e pluviosidade foram registrados mensalmente em cada transecto. Os espécimes foram medidos quanto ao comprimento do somito pré-bucal (SL). Os resultados mostram que nas zonas mais rasas (Z1 e Z2) foram coletados 6306 indivíduos, enquanto que na mais profunda (Z3) obteve-se 3808 espécimes, não havendo diferença estatística entre as zonas (ANOVA, $\mathrm{p}=0.25$ ). A abundância não diferiu estatisticamente entre as estações do ano (Tukey, $\mathrm{p}=0.02$ ), exceto para a primavera. Em todas as estações amostradas, o sex ratio diferiu estatisticamente $\left(\chi^{2}, p<0.05\right)$. Os fatores ambientais aqui analisados apresentaram relação estreita com a distribuição espaço-temporal de L. faxoni. A pluviosidade influenciou diretamente a salinidade, que provocou o deslocamento dos camarões $L$. faxoni para áreas mais profundas.

Descriptors: Abundance, Population structure, Ecologic distribution, South Atlantic, Decapoda. Descritores: Abundância, Estrutura populacional, Distribuição ecológica, Atlântico Sul, Decapoda. 


\section{INTRODUCTION}

According to Costa et al. (2000), the genus Lucifer Thompson, 1829, includes only two species that occur along the Brazilian coast: Lucifer faxoni Borradaile, 1915, and L. typus Milne-Edwards, 1837. L. faxoni occurs throughout the western Atlantic Ocean, with its northern limit in Nova Scotia, Canada, and its southern limit in the State of Rio Grande do Sul, Brazil. This species exhibits a planktonic habit, occurring from depths of 6 to 55 meters, but is usually found in coastal waters (D'INCAO, 1997). L. faxoni also has a short life span and high growth rates, engages in sequential spawning and protects its eggs during incubation (LEE et al., 1992). This species is not pleopodal like other decapods but incubates its eggs under the thoracic somites. Few studies have investigated this species, and most studies have focused on the occurrence of the Lucifer genus (OMORI, 1977; D'INCAO, 1997; COSTA et al., 2000). Specific studies on L. faxoni have investigated its geographical and/or ecological distribution (BOWMAN; MCCAIN, 1967; HARPER JR, 1968; TROOST, 1975; $\quad$ ALVAREZ, 1985 SANKARANKUTTY ;BARCA, 2000; FERNANDES et al., 2002; PASCUAL et al., 2002). López (1966) reported that $L$. faxoni is the most frequent decapod in planktonic collections.

The relationship among environmental factors and the abundance of penaeoidean shrimps have been studied by several authors. Costa et al. (2005 a,b; 2007) emphasized the importance of parameters such as salinity, temperature and sediment texture, in habitat selection by commercially exploitable penaeid shrimps such as Xiphopenaeus kroyeri Heller, 1862 and Artemesia longinaris Bate, 1888. Luciferid shrimps exhibit an epipelagic habit, remaining close to the substrate during the day (WOODMANSEE, 1966). As a result of this epipelagic behavior, sediment texture likely does not influence the distribution of this species.

Lucifer faxoni is an important component of the pelagic and coastal ecosystem (LEE et al., 1992), and the importance of the communities of which this species is a member is irrefutable. This species is part of the diet of coastal fishes (PASCUAL et al., 2002) such as the cutlassfish Trichiurus lepturus Linnaeus, 1758 (MARTINS et al., 2005) and large filter feeders such as the whale shark Rhincodon typus Smith, 1828 (MOTTA et al., 2010). Moreover, the zooplanktonic communities to which Lucifer belongs are among the most important components of marine ecosystems because of their role in nutrient recycling and the distribution of organic matter (VEGA-PÉREZ, 1993). Zooplankton are also important for their use as a research tool to investigate the impact of pollutants on marine communities (EPOPEM, 1979; SIOKOU-
FRANGOU; PAPATHANASSIOU, 1991). In this context, additional studies on the biology of Lucifer faxoni are extremely important. These studies will add to knowledge on this species but can also contribute to studies on the conservation and ecology of L. faxoni and the food chain to which it belongs. The aim of the present study is to provide an ecological analysis of the shrimp L. faxoni in Ubatuba Bay on the northern coast of the State of São Paulo, Brazil.

\section{Material and Methods}

Sampling was conducted at Ubatuba Bay on the northern coast of the State of São Paulo (23⒉ ' $23^{\circ} 27^{\prime} \mathrm{S}$; 45 $05^{\circ}-4^{\circ} 03^{\prime} 18^{\prime \prime} \mathrm{W}$ ) (Fig. 1). Sampling was performed using a small fishing boat with a $25-$ HP stern-drive engine. The specimens of $L$. faxoni were sampled monthly from July 2005 to December 2006 with a Renfro net (RENFRO, 1963) measuring 1 $\mathrm{m}$ at the mouth aperture and with a $1-\mathrm{mm}$ mesh size, that was trawled over a distance of $50 \mathrm{~m}$ for a total sampling effort of $50 \mathrm{~m}^{2}$ per station. Nine stations were sampled, ranging from depths of 1 to $15 \mathrm{~m}$. Three stations each were grouped into zones 1,2 and 3 , named Z1 (closed areas with little or no wave influence), Z2 (open areas influenced by wave action) and Z3 (deeper waters). Each sampling site was subdivided in 3 areas, each including 3 stations (Z1, $\mathrm{Z} 2$ and $\mathrm{Z3}$ ). In the laboratory, all samples were identified in accordance with D'INCAO (1997) and PÉREZ-FARFANTE (1997) and measured, sexed, and stored in $10 \%$ formaldehyde.

Measurements were taken with a microscope stereoscope equipped with an ocular micrometer with a resolution of 10/100 mm. For each month sampled, frequency distributions of the pre-buccal somite length (SL) were made, on the basis of size classes of 0.8 $\mathrm{mm}$. At each station, the bottom temperature and salinity were recorded monthly using a Van Dorn bottle for water sampling. Rainfall rates in the region were provided by the "Instituto Agronômico" (IAC) through the official website of the institute (http://www.iac.sp.gov.br/).

For size analyses, measurements (in $\mathrm{mm}$ ) of the pre-buccal somite length (SL) of $L$. faxoni were used. In samples with a large number of captured individuals, only 100 individuals of each sample were utilized in the analysis. When the number of L. faxoni was lower than 100 , all the individuals in the sample were measured. The SL was measured as the distance from the labrum anterior margin to the base of the eyestalk. This parameter appears to be applicable for analyses of the developmental stages of $L$. faxoni, as shown by López (1966), Woodmansee (1966), Costa and Prandi (1971) and Alvarez (1988). The abundance was compared among stations and seasons of the year using analysis of 
variance (two-way ANOVA with interaction, $\mathrm{p}<0.05$ ), complemented by Tukey's multiple-comparisons test, at the 5\% probability level. For the environmental factor association in relation to species abundance, a multiple linear regression was used. Data were logtransformed prior to the analysis to improve their normality (ZAR, 1996). The sex ratio during the period sampled was tested using the chi-squared test $\left(\chi^{2}\right)$ at a $5 \%$ level of significance.

\section{REsults}

A total of 10,114 individuals were captured, 6306 in waters shallower than 5 meters (Z1 and Z2) and 3808 in regions with depths of 10 to 15 meters (Z3), with no significant differences between the number of individuals captured in each zone (ANOVA, $\mathrm{p}=0.25$ ). The comparison of abundance revealed a significant difference only among seasons of the year (two-way ANOVA with interaction, $\mathrm{p}=0.002$ ). Only winter and spring seasons differed significantly (Tukey's test, $\mathrm{p}=0.002$ ). There were no significant differences among the stations sampled (two-way ANOVA with interaction, $\mathrm{p}=0.305$ ) (Table $1)$.

Of the total number of shrimps captured, 2784 were measured and sexed. With the exception of spring 2006 (October, November and December), males outnumbered females in all of the sampling periods. In all seasons of the year, the sex ratio differed significantly $\left(\chi^{2}, \mathrm{p}<0.05\right)$, with the male to female ratio at 1.48:1 (Fig. 2).

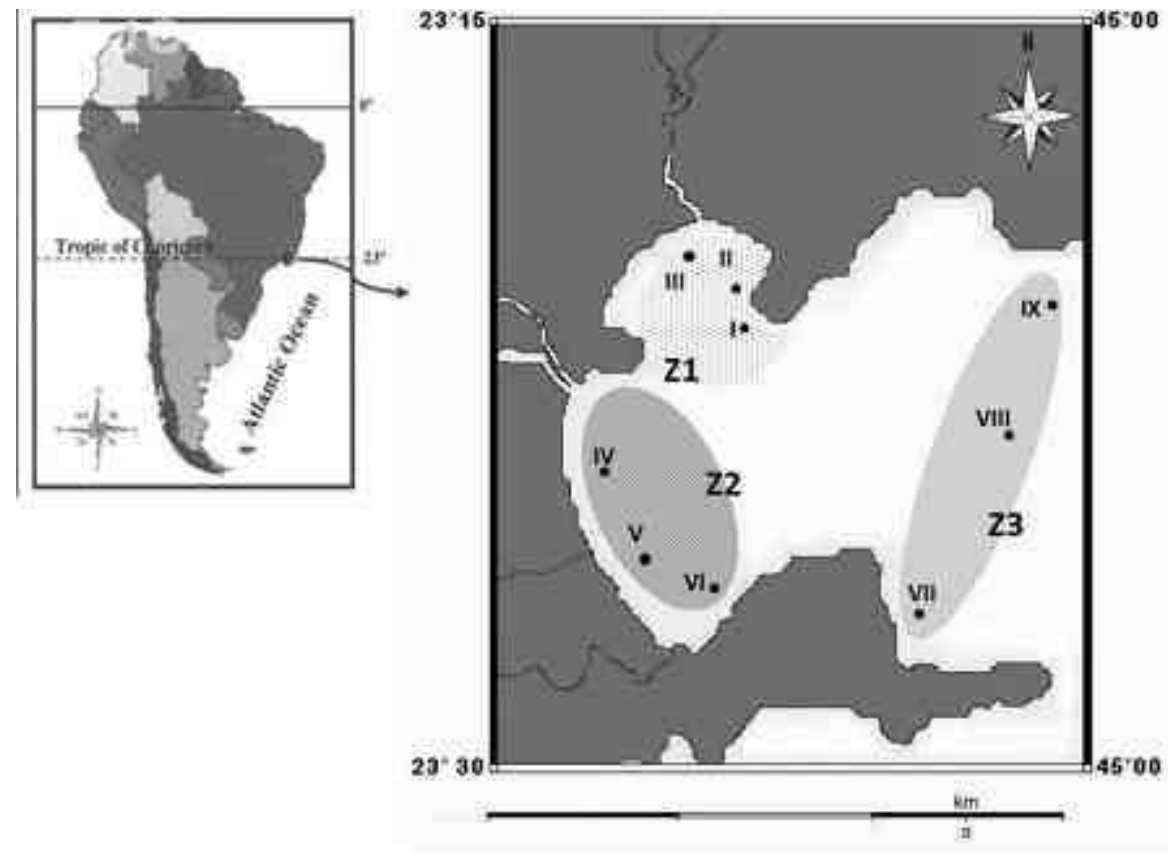

Fig. 1. Map of Ubatuba Bay, Brazil, indicating the sampled stations and the zones established (Z1, Z2 and Z3).

Table 1. Lucifer faxoni. Results of the analysis of variance (twoway ANOVA with interaction) of the mean catch by season and station.

\begin{tabular}{llllll}
\hline \hline Source of variation & \multicolumn{1}{c}{$\mathbf{d F}$} & \multicolumn{1}{c}{ MS } & \multicolumn{1}{c}{$\mathbf{F}$} & \multicolumn{1}{c}{$\mathbf{P}$} \\
\hline Season & 5 & 267406.8 & 4.642 & $<0.001$ \\
Station & 8 & 69230.4 & 1.202 & 0.305 \\
Season $x$ Station & 40 & 62691.7 & 1.088 & 0.358 \\
Residual & 108 & 57609.1 & & \\
Total & 161 & 65964.8 & & \\
\hline
\end{tabular}

$\mathrm{df}=$ degrees of freedom, MS = mean square, $\mathrm{F}=\mathrm{MS}$ factor/MS residual and $\mathrm{p}=$ probability of significance; $\alpha=0.05$. 


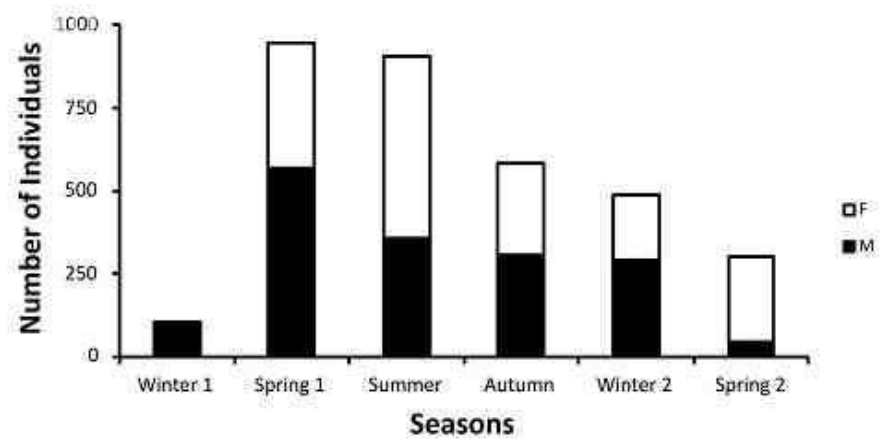

Fig. 2. The sex ratio of Lucifer faxoni in each season during the sampling period.

Spatially, Zone 1 (areas shallower than 5 meters) exhibited the highest abundance $(1,101$ measured shrimps), followed by Zones 2 (859) and 3
(794). The sex ratio for each size class in each zone is shown in Figure 3. Once again, the predominance of males compared to females can be clearly observed.

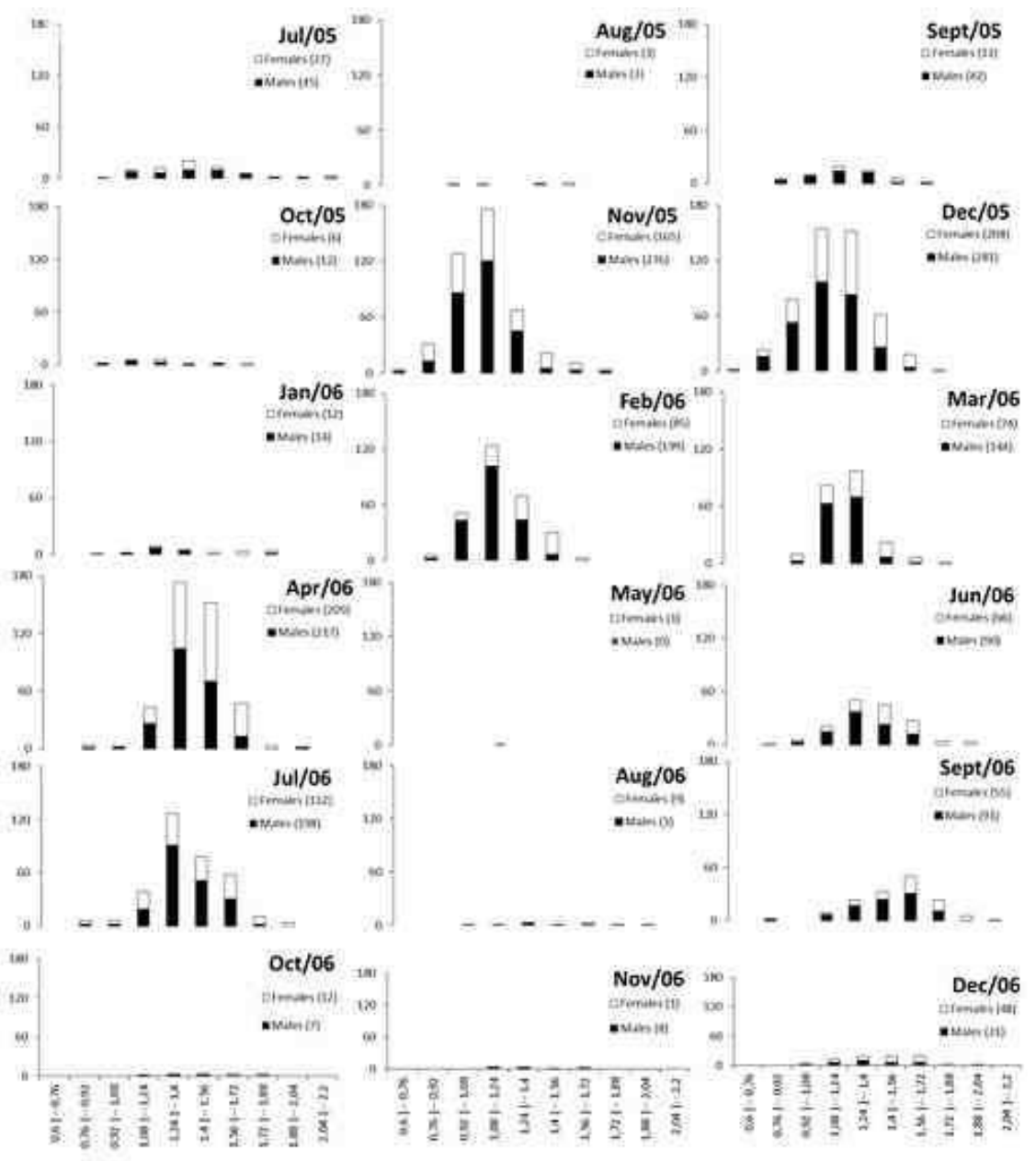

Fig. 3.The sex ratio in each size class (mm) of Lucifer faxoni found in each zone sampled in the study period. $\mathrm{M}=$ males; $\mathrm{F}=$ females. 
The average of pre-buccal somite length (SL) found for $L$. faxoni was $1.28 \mathrm{~mm}$. The sex ratio for each size class and for each sampled month is presented in Figure 4. In July and December 2005, individuals were found in all size classes. Individuals classified in the smallest size classes were found in 2005 (July, October and December) and 2006 (January, February, March, July and September). Shrimps with average SL were observed in all months of the year except May 2006. The smallest male and the smallest female had an SL of $0.70 \mathrm{~mm}$; the largest individuals of each sex had an SL of $2.11 \mathrm{~mm}$. Females exhibited a mean SL of $1.32 \mathrm{~mm}$, whereas males exhibited a mean SL of $1.24 \mathrm{~mm}$.

A positive correlation between the abundance of $L$. faxoni and rainfall was found (multiple linear regression, $\mathrm{p}=0.00$ ) (Table 2), whereas other factors did not present a positive correlation. The same test was conducted - excluding rainfall - and temperature and salinity were not significant factors affecting $L$. faxoni distribution. In fact, $L$. faxoni abundance was higher when rainfall values increased. When these values decreased, this shrimp's abundance also decreased, except in the spring (October, November and December) of 2006 (Fig. 5).

Only 4 females with egg masses were found, 2 of which were in summer 2005 (Table 3). A reproductive analysis of ovigerous females was not possible because the eggs are too easily released from the females. The SL of ovigerous females ranged from 0.94 to $1.41 \mathrm{~mm}$, but the number of females with eggs was not high enough for a reliable analysis.

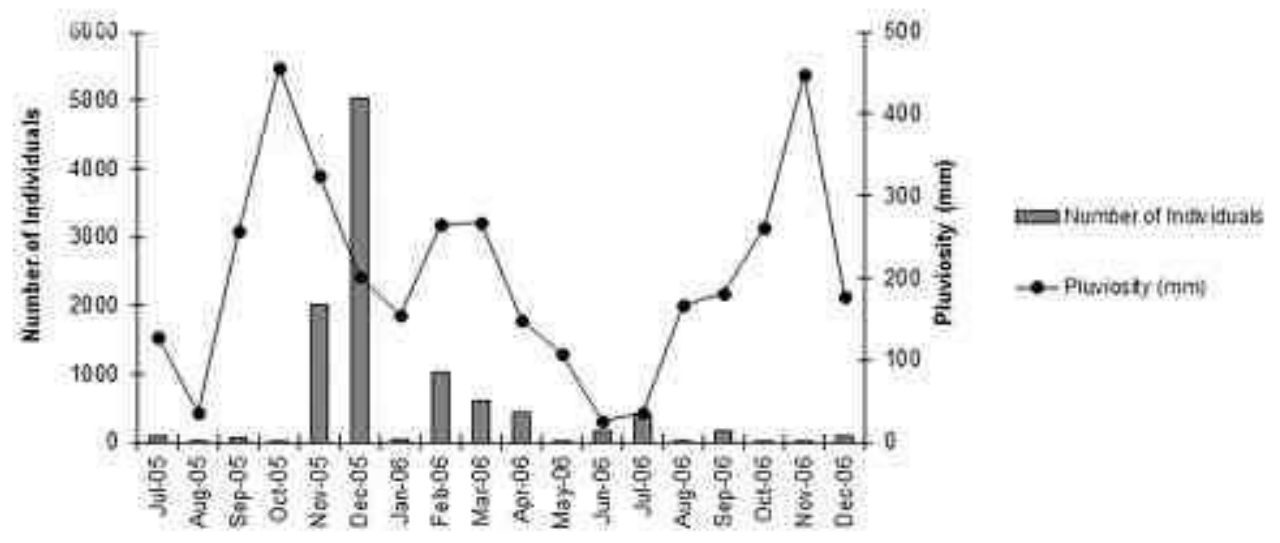

Fig. 4. Monthly distribution of males and females of Lucifer faxoni in each size class based on somite length.

Table 2. Multiple Linear Regression of the mean catch of Lucifer faxoni. by environmental factors, considering and not considering rainfall.

\begin{tabular}{lllll}
\hline \hline & Coefficients & $\overline{\text { Standard Error }}$ & $\overline{\text { Stat t }}$ & $\overline{\text { P-value }}$ \\
\hline Intercept & -0.403 & 2.502 & -0.161 & 0.872 \\
Temperature & -0.527 & 1.480 & -0.356 & $\mathbf{0 . 7 2 2}$ \\
Salinity & 0.506 & 0.662 & 0.764 & $\mathbf{0 . 4 4 6}$ \\
Rainfall & 0.529 & 0.067 & $\mathbf{7 . 8 8 7}$ & $\mathbf{0 . 0 0 0}$ \\
\hline & Coefficients & Standard Error & Stat $\boldsymbol{~} \boldsymbol{\text { St }}$ & $\mathbf{P \text { -value }}$ \\
\hline Intercept & -1.41 & 2.94 & -0.48 & 0.63 \\
Temperature & 1.38 & 1.72 & 0.81 & 0.42 \\
Salinity & 0.08 & 0.78 & 0.10 & 0.92 \\
\hline
\end{tabular}




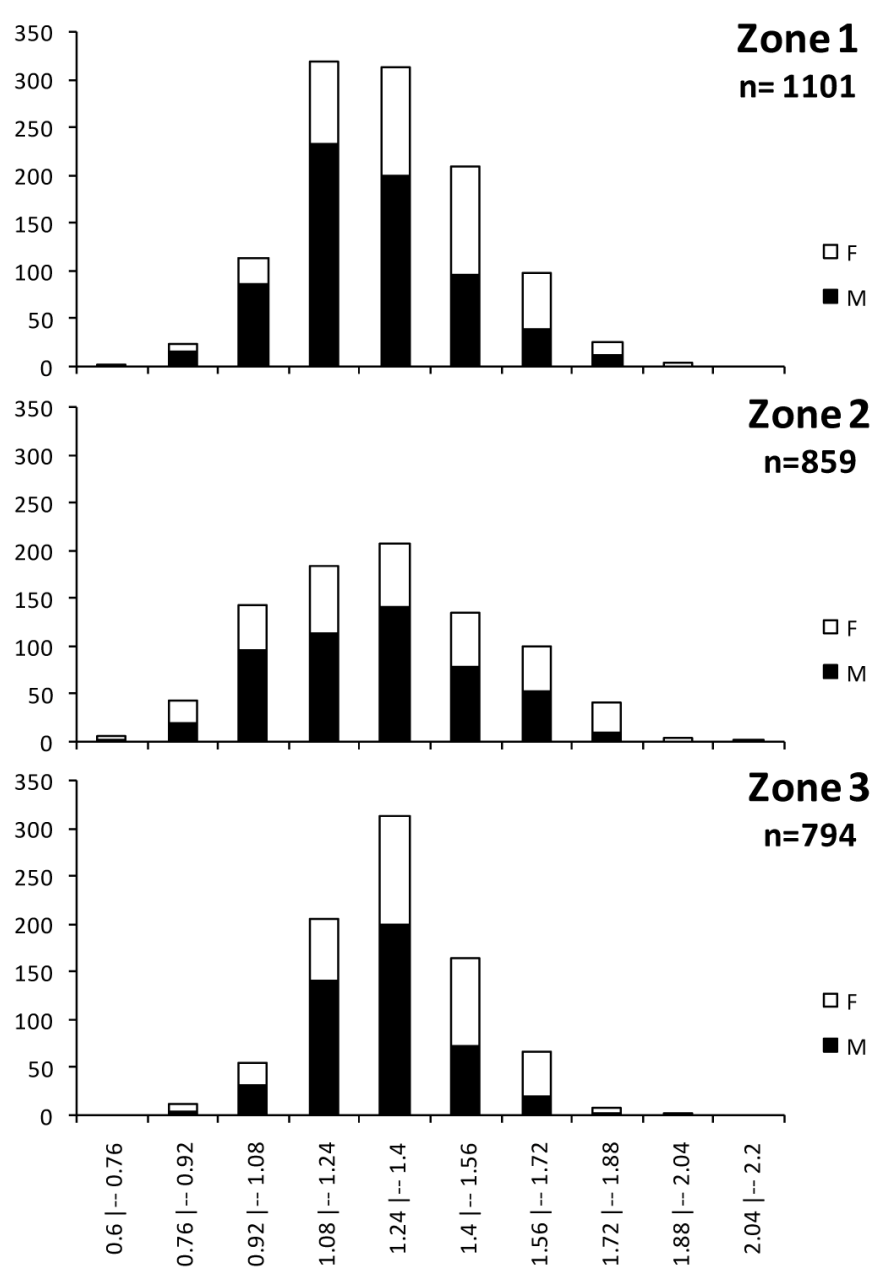

Fig. 5. Variation in number of individuals and mean monthly rainfall during the sampling period.

Table 3. Distribution of the breeding females of Lucifer faxoni on the depth zones.

\begin{tabular}{ccccc}
\hline \hline Date & Zone & Breeding Females & Somit Length $(\mathbf{m m})$ & $\overline{\text { Number of eggs }}$ \\
\hline Oct-05 & $\mathrm{Z} 1$ & 1 & 1.41 & 13 \\
Nov/05 & $\mathrm{Z} 2$ & 1 & 1.17 & 1 \\
Aug/05 & $\mathrm{Z} 1$ & 1 & 1.64 & 4 \\
Jul/06 & $\mathrm{Z} 3$ & 1 & 0.94 & 1 \\
\hline
\end{tabular}

\section{Discussion}

With regard to the correlation observed between L. faxoni abundance and rainfall, we suggest that this factor may have influenced salinity values in shallow regions, causing the shrimps to move to deeper areas. López (1966) reported that $L$. faxoni did not occur in regions under the influence of waters with salinity levels lower than 36 psu. In contrast, Alvarez (1985) and Bowman and McCain (1967) found that L. faxoni has a preference for salinities close to $30 \mathrm{psu}$, a similar value to that recorded in the present study. The difference in abundance observed in these studies may have resulted from the year-round variability in rainfall. With less rain and a consequently lower variation in salinity in shallow areas, winter would be the most consistent 
season for the larval development of $L$. faxoni, which would lead to an increase in population the following spring. Surface waters exhibit a higher fluctuation in salinity in the summer due to the greater amount of rainfall. Lucifer larvae hatched under these conditions would have a lower survival rate, i.e., they could not complete their life cycle, and this fact would reduce the shrimp population in the subsequent seasons.

According to Razouls and Thiriot (1968), variations in the amount of biomass represented by zooplankton taxa would be a response to variations in temperature, considering that temperature regulates the life cycle of these organisms. Although it was not significant in the present study, temperature was likely a decisive factor affecting the low abundance of $L$. faxoni found in the spring of the second study year. The present study was performed in shallow waters $(<$ 15 meters) and, consistent with the findings of CastroFilho et al. (1987), it can be assumed that these areas are influenced by coastal water $(\mathrm{CW})$, which is characterized by salinity levels that range from 33 to $35 \mathrm{psu}$ and temperatures higher than $20^{\circ} \mathrm{C}$ and is incorporated with tropical water (TW). In the spring and early summer, the incursion of a relatively cold $(<$ $\left.20^{\circ} \mathrm{C}\right)$ and less saline $(<36.4)$ water mass, called SACW (South Atlantic Central Water), commonly occurs. The mixing zone is observed near the coast (including the region studied), creating a strong thermocline (in the winter, there is no substantial inflow of SACW on the inner shelf) (CASTROFILHO et al., 1987). The presented data indicates an influx of SACW at the end of 2006, when the bottom temperature reached values below $18^{\circ} \mathrm{C}$. Previous studies (COSTA et al., 2004; 2005a) showed that, due to the entrance of SACW, a decrease in the temperature of the outer region of the inlet promoted the migration of other Dendrobranchiata shrimps, such as Pleoticus muelleri (Bate, 1888) and Artemesia longinaris. Other species, such as Sicyonia dorsalis Kingsley, 1878, and Xiphopenaeus kroyeri, migrated from this region to deeper waters in the middle of the bays (e.g., Ubatuba Bay), where temperature values were higher (COSTA et al., 2005b; 2007). The low numbers of $L$. faxoni individuals recorded in January and mainly in November and December, 2006 were likely associated with the intrusion of this water mass.

The sex ratio determined in the present study differs from that described in previous studies on $L$. faxoni. For example, López (1966), studying the same species at Cananéia (SP, Brazil), found a higher number of females than males. In contrast, Alvarez (1985) obtained a higher abundance of males than females in a study undertaken on the coast of Santos. Sex ratios have been very variable in other shrimp species. For example, in a study of X.kroyeri, Cortés (1991) reported a sex ratio of $1 \delta^{\lambda}: 0.7$, and in a study of Acetes americanus Ortmann, 1893, Simões (2008) found a predominance of females over males $(0.5: 1)$. According to Lee et al. (1992), L. faxoni females migrate vertically during the night, both to avoid predation and in search of more abundant food resources or for egg protection. Females may cluster in regions with more appropriate conditions, such as areas of more abundant food resources, which would account for the difference in the number of males and females found in the present study. In this case, alterations in sex ratios may result from the grouping of females in particular areas during spawning (SIMÕES, 2008). Dendrobranchiata shrimps generally move to deeper areas to spawn (DALL et al., 1990).

The fact that very few ovigerous females were found may have resulted from the fact that females lost their eggs, both during sampling and at the time of fixing (LOPÉZ, 1966). Despite the low number of ovigerous females, the sampling period found in the present study coincides with Lopéz (1966) and Alvarez's (1985) results, which likely indicates a longer reproduction period at this time, i.e., during the spring months. Females were predominant at stations 3 and 7, both of which are located close to river mouths. These locations tend to harbor a greater quantity of phytoplankton, which, according to Lee et al. (1992), is the preferred food of Lucifer larvae. Because the females carry the eggs, they are likely to remain in places that are more favorable for larval development until hatching, which would explain the dominance of females at these stations.

For L. faxoni, there are no studies focusing on species recruitment. However, Fernandes et al. (2002), studying the dynamics of decapod larvae in Guanabara Bay, suggest that L. faxoni has a seasonal distribution pattern: in the winter, larvae are imported into the bay to complete their development inside the estuary, and in the summer, non-reproductive adults are exported to coastal waters. In this way, as for the sergestid A.americanus studied by Simões (2008), $L$. faxoni appears to present recruitment peaks during October and November. The largest females were found in November and December, 2005 and in April and July, 2006, which suggests the occurrence of reproduction periods at these times. These results are in agreement with Lopéz (1966), who found a higher number of reproductive females during the summer and autumn. Alvarez (1985) found a higher number of L. faxoni of reproductive age in September.

As in the present study, Alvarez (1988) found $L$. faxoni females to be larger than males. These results are similar to the findings for other penaeid shrimps, such as X.kroyeri, studied by Cortés (1991), and Litopenaeus schmitti (Burkenroad, 1936), studied by Davant (1963) and Ewald (1967). This finding indicates that sexual dimorphism, with respect to length, is a general rule among penaeoideans, with 
females larger than males. Gab-Alla et al. (1990), Rodrigues et al. (1992), Santos (2000) and Santos and Ivo (2000) found that the male carapace grows differently from that of females as a result of a process associated with reproduction. This fact has been observed for penaeid species such as Rimapenaeus constrictus (Stimpson, 1874), X.kroyeri and A.longinaris, which were studied by Costa and Fransozo (2004), Castro et al. (2005) and Castilho et al. (2007), respectively. With respect to sergestid shrimps, some studies have also presented similar results, including that by $\mathrm{Oh}$ and Jeong (2003) for Acetes chinensis (Hansen, 1919) and that by Simões (2008) for Acetes americanus and Peisos petrunkevitchi Burkenroad, 1945.

According to Lee et al. (1992), L. faxoni reaches sexual maturity at approximately 19 days and, preferentially, in locations with temperatures close to $30^{\circ} \mathrm{C}$, which helps to explain the higher number of individuals found during the autumn months. As a result of the high temperatures characteristic of the summer, females experience a higher reproductive peak, and a greater frequency of spawning may occur in subsequent months. This may explain the abundance of smaller and average-sized individuals found during the period of the present study.

The low concentration of $L$. faxoni among the smallest size classes may be associated with the fact that larvae and immature juveniles of this species often concentrate more at the surface than near the bottom. This concentration of larvae at the surface generally occurs because of the greater amount of phytoplankton, which acts as a barrier to the larvae, intercepting them in such a way as to maintain them in these areas (ALVAREZ, 1985). In summary, the environmental factors monitored here have a close relation to the spatial and seasonal distribution of $L$. faxoni. The intensity of the rainfall directly affected salinity in such a way as to promote the displacement of these shrimps to deeper areas, whereas temperature mainly influenced the variation in seasonal abundance. Additional studies on reproduction and population dynamics are necessary for a better understanding of the life cycle of this species. Although there have been few studies on reproductive analyses of $L$. faxoni, the findings of the present study are in agreement with those of the existing literature. Further investigation of the vertical migration, histology and morphological descriptions of this species will make it possible to describe its reproductive biology in greater detail.

\section{ACKNOWLEDGEMENTS}

The authors are indebted to the "Fundação de Amparo à Pesquisa do Estado de São Paulo" (FAPESP) for providing financial support during field collections and laboratory activities (Grants 2004/07309-8, 2007/58094 2009/54672-4 and
2010/50188-8 to RCC and 1998/03134-6 to MLNF) and to CNPq (Research Scholarships PQ 306304/2008-2 to RCC and PQ 300481/2008-0 to MLNF). Thanks are extended to the staff at NEBECC and LABCAM for their help with sampling and laboratory activities, especially to Adilson Fransozo and Antonio L. Castilho.

\section{REFERENCES}

ALVAREZ, M. P. J. Migração vertical de Lucifer faxoni Borradaile, 1915 (Crustacea-Decapoda) nas águas ao largo de Santos, Brasil. Bol. Inst. Oceanogr., São Paulo, v. 9, p. 177- 193. 1985.

ALVAREZ, M. P. J. Estudo do desenvolvimento de Lucifer faxoni Borradaile, 1915 (Crustacea, Decapoda, Sergestidae) através das medidas do somito pré-bucal. Rev.Bras. Zool., v. 5, n. 3, p.371-379, 1988.

BOWMAN, T. E.; MCCAIN, J.C. Distribution of the planktonic shrimp, Lucifer, in the Western North Atlantic. Bull. Mar. Sci, v. 17, p. 660-671, 1967.

CASTILHO, A.L.; GAVIO, M.A.; COSTA, R.C.; BOSCHI, E.E.; BAUER, R.T.; FRANSOZO, A. Latitudinal variation in population structure and reproductive pattern of the endemic South American shrimp Artemesia longinaris (Decapoda: Penaeoidea). J. Crustacean Biol., v. 27 , n. 4 , p.548-552. 2007.

CASTRO, R. H.; COSTA, R. C.; FRANSOZO, A.; MANTELATTO, F. L. M. Population structure of the seabob shrimp Xiphopenaeus kroyeri (Heller, 1862) (Crustacea: Penaeoidea) in the littoral of São Paulo, Brazil. Sci.Mar., v. 69, n. 4, p. 105-112. 2005.

CASTRO-FILHO, B. M.; MIRANDA, L. B.; MYAO, S. Y. Condições hidrográficas na plataforma continental ao largo de Ubatuba: variações sazonais e em média escala. Bol. Inst. Ocean., São Paulo, v. 35, n. 2, p. 135-151, 1987.

CORTÉS, M. L. Aspectos reproductivos del camaron Xiphopenaeus kroyeri (Heller) en Costa Verde, Cienaga (Caribe Colombiano). Caldasia, v. 16, p. 513-517, 1991.

COSTA, R. C.; FRANSOZO, A. Reproductive biology of the shrimp Rimapenaeus constrictus (Decapoda, Penaeidae) in the Ubatuba Region of Brazil. J. Crustacean Biol., v. 24, n. 2, p. 274-281, 2004

COSTA, H. R.; PRANDI, N. R. W. Estudo da distribuição das espécies do gênero Lucifer em amostras de plâncton coletadas entre Cabo Frio e a Baía de Santos. Arq. . Nac. Rio de Janeiro, v.54, p. 159-170, 1971.

.COSTA, R. C., FRANSOZO, A., MANTELATTO, F. L. M.; CASTRO, R. H. Occurrence of shrimp species (Natantia: Penaeidea: Caridea) in Ubatuba Bay, Ubatuba, SP, Brazil. Proc. Biol. Soc. Wash.,v. 113, n. 3, p. 776-781, 2000.

COSTA, R. C.; FRANSOZO, A.; PINHEIRO, A. P. Ecologic distribution of the shrimp Pleoticus muelleri (Bate, 1888) (Decapoda: Penaeoidea) of Southeastern Brazil. Hydrobiologia (The Hague), v. 529, n. 1, p. 195-203, 2004.

COSTA, R. C.; FRANSOZO, A.; CASTIlHO A. L.; FREIRE, F. A. M. Annual, seasonal and spatial variation of abundance of the shrimp Artemesia longinaris (Decapoda; Penaeoidea) in south-eastern Brazil. J. Mar. Biol. Assoc. U.K., v. 85, p. 107-112, 2005a. 
COSTA, R. C.; FRANSOZO, A.; NEGREIROSFRANSOZO, M. L. Ecology of the rock shrimp Sicyonia dorsalis Kingsley, 1878 (Crustacea: Sicyoniidae) in a subtropical region of Brazil. Gulf Caribbean Res.,v.17, n. 1, p. 49-56, 2005 b.

COSTA, R. C.; FRANSOZO, A.; FREIRE, A. M.; CASTILHO, A. L. Abundance and ecological distribution of the "sete-barbas" shrimp Xiphopenaeus kroyeri (Heller, 1962) (Decapoda: Peanaeoidea) in three bays of the Ubatuba region, Southeastern Brazil. Gulf Caribbean Res.,v.19, p. 33-41, 2007.

D'INCAO, F. Espécies do gênero Lucifer Thompson, 1829 no litoral brasileiro (Decapoda: Luciferidae). Nauplius, Rio Grande, v. 5, n. 2, p. 139-145. 1997.

DALL, W.; HILL, B. J.; ROTHILSBERG, P. C.; STAPLES, D. J. The biology of the Penaeidae. In: BLAXTER, J.H.S.;SOUTHWARD, A. J. (Ed.). Advances in Marine Biology. San Diego: Academic Press, 1990. v. 27, 489 p.

DAVANT, P. Clave para la identificación de los camarones marinos y de río con importancia económica en el oriente de Venezuela. Cuad. Oceanogr., v.1, p. 42-47, 1963.

EPOPEM. Systeme planctonique et pollut on urbalne. Un aspect des populations zooplanctoniques. Oceanologica Acta, v.2, n.4, P.379-388, 1979.

EWALD, J. J. Estudio sobre la biología del camarón blanco Penaeus schmitti. Burkenroad. Acta Cient. Venezolana, p. 190-200, 1967.

FERNANDES, L. D. A.; BONECKER, S. L. C.; VALENTIN, J. L. Dynamic of decapod crustacean larvae on the Entrance of Guanabara Bay. Braz. Arch. Biol. Technol., v. 45, n. 4, p. 491-498, 2002.

GAB-ALLA, A. A.; F. A., HARTNOLL, R.G., GHOBASHY, A. -F. \& MOHAMMED S. Z. Biology of penaeid prawns in the Suez Canal lakes. Mar. Biol., v. 107, p. 417-426, 1990.

HARPER JR, D. E. Distribution of Lucifer faxoni (Crustacea: Decapoda: Sergestidae) in neritic waters off the Texas Coast, with a note on the occurrence of Lucifer typus. Contr. Mar. Sci., v. 13, p. -16. 1968.

LEE, W. Y.; OMORI, M.; PECK, R. W. Growth, reproduction and feeding behavior of the planktonic shrimp, Lucifer faxoni Borradaile, off the Texas Coast. J. Plank. Res.,v. 14, n. 1, p. 61-69, 1992.

LÓPEZ, M. T. Biología de Lucifer faxoni Borradaile, 1915, em Cananéia, Brasil (Crustacea, Decapoda, Luciferidae). Bol. Inst. Oceanogr., São Paulo,v. 15, n. 1, p. 47-54, 1966.

MARTINS, A. S.; HAIMOVICI, M.; PALACIOS, R. Diet and feeding of the cutlass fish Trichiurus lepturus in the Subtropical Convergence Ecosystem of southern Brazil. J. Mar. Biol. Assoc. U. K., v. 85, p. 1223-1229, 2005.

MOTTA, P. J.; MASLANKA, M.; HUETER, R. E.; DAVIS, R. L.; de LA PARRA, R.; MULVANY, S.L.; HABEGGER, M.L.; STROTHER, J.A.; MARA, K.R.; GARDINER, J.M.; TYMINSKI, J.P.; ZEIGLER, L.D. Feeding anatomy, filter-feeding rate, and diet of whale sharks Rhincodon typus during surface ram filter feeding off the Yucatan Peninsula, Mexico. Zoology, v. 113, p.199-212. 2010.

OH, C. W.; JEONG, I.J. Reproduction and Population dynamics of Acetes chinensis (Decapoda: Sergestidae) on the Western coast of Korea, Yellow Sea. J. Crustacean Biol., v. 23, n. 4, p. 827-835. 2003.
OMORI, M. Distribution of warm water epiplanktonic shrimps of the genera Lucifer and Acetes (Macrura, Penaeidea, Sergestidae). SYMPOSIUM ON WARM WATER ZOOPLANKTON, Unesco/NIO, 1977. Proceedings... p. 1-12, 1977.

PASCUAL,C. R.; WAKABAR, Y.; FLYNN, M. N. Composition, distribution and temporal variation of a suprabenthic community of Ribeira Bay, Angra dos Reis, Sotheastern Brazil. Oceánides,v. 17, n. 1, p. 41-56. 2002.

PÉREZ-FARFAnTE, I.; KENSLEY, B. Penaeoid and segestoid shrimps and prawns of the world. keys and diagnoses for the families and genera. Paris: Éditions du Muséum National d'Histoire Naturelle, 1997. 233p.

RAZOULS, S.; THIRIOT, A. Le macrozooplancton de la region de Banyuls-sur-Mer (Golfe du Lion). Vie Milieu, v.19, n. 1B, p.133-184, 1968.

RENFRO, W. C. 1963. Small beam for sampling postlarval shrimp. Circ. U. S. Dept. Fish. Wildl. Serv., v. 161, p. 86-87, 1963.

RODRIGUES, E. S.; PITA, J. B.; LOPES, R. G.; COELHO, J. A. P.; PUZZI, A. Aspectos biológicos e pesqueiros do camarão sete-barbas (Xiphopenaeus kroyeri) capturado pela pesca artesanal no litoral do Estado de São Paulo.Bolm Inst. Pesca, S Paulo, v. 19, p. 67-81, 1992.

SANKARANKUTTY, C.; BARCA, F. E. N. Some observations on Lucifer faxoni Borradaile (Crustacea: Decapoda; Sergestidae) collected from a tidal estuary. J. Mar. Biol. Ass. India, , v. 41, n. 1, 2, p.103-106, 2000.

SANTOS, M. C. F. Biologia e pesca de camarões marinhos ao largo de Maragogi (Alagoas-Brasil). Bol. Técn.Cient. CEPENE, v. 8, n. 1, p. 99-129, 2000.

SANTOS, M. C. F; IVO, C. T. Pesca, biologia e dinâmica populacional do camarão sete-barbas, Xiphopenaeus kroyeri (Heller, 1862) (Crustacea: Penaeidae) capturados em frente ao município de Caravelas (Bahia-Brasil). Bol. Técn.-Cient. CEPENE,v. 8, n. 1, p. 131-164, 2000.

SIMÕES, S. M. Distribuição e Dinâmica Populacional dos Camarões Sergestídeos, Acetes americanus americanus Ortmann, 1893 e Peisos petrunkevitchi Burkenroad, 1945 (Dendrobranchiata, Sergestidae), na região de Ubatuba, Litoral Norte do Estado de São Paulo. 2008. 90p., Universidade Estadual Paulista, Instituto de Biociências, Botucatu, SP. Master Science Dissertation.

SIOKOU-FRANGOU, I.; PAPATHANASSIOU, E. Differentiation of zooplankton populations in a polluted area. Mar. Ecol. Progr. Ser., v. 76, p.41-51, 1991.

TROOST, D. G. The sergestid shrimp Lucifer in the 1970 Cicar plankton samples taken by H. M. S. "Luymes", with notes on the Amazon river as a nutrient source. Bull. Zool. Mus., v. 24, n. 4, p. 201-211, 1975.

VEGA-PÉREZ, L. A.; ARA, K.; LIANG, T. H.; PEDREIRA, M. M. Feeding of the planktonic shrimp Lucifer faxoni Borradaile, 1915 (Crustacea: Decapoda) in the laboratory. Rev. Bras. Oceanogr., v. 44, n. 1, p.1-8, 1993.

WOODMANSEE, R. A. Daily vertical migration of Lucifer. Planktonic numbers in relation to solar and tidal cycles. Ecology, v. 47, n. 5, p. 847-850, 1966.

ZAR, J. H. Biostatistical Analysis. Upper Saddle River, NJ Prentice-Hall, 1996. 662 p.

(Manuscript received 13 Dece,ber 2011; revised 16 January 2012; accepted 16 February 2012) 